Send your letters to the Editor,

British Dental Journal

64 Wimpole Street

London

W1G 8YS

Email bdj@bda.org

Priority will be given to letters less than 500 words long.

Authors must sign the letter, which

may be edited for reasons of space.

\section{FORMOCRESOL ALTERNATIVES}

Sir, I am writing to contribute to the debate on formocresol use in children for primary molar pulp therapy in response to recent letters. ${ }^{1,2}$

Formocresol has been used for many decades in paediatric dental practice and beyond doubt has been one of the most successful pulp medicaments. Moreover, seldom have any side effects or toxicity been reported that have arisen out of its clinical use. However, there are questions about the safety, about the chemicals that constitute this therapeutic material, in particular formaldehyde and cresol, albeit in concentrations far in excess of what is present in the solution for dental use. It is unthinkable that any such chemicals with even a remoter link to any toxicity will ever be allowed to be used in any other surgical practice in children and it seems to be a matter of time before the authorities will clamp down on the use of formocresol in dentistry.

In addition there are alternatives that have been shown to be as efficacious and so far with no toxicity. In a prospective randomised control trial comparing formocresol with ferric sulphate, the only such well conducted study, a comparable efficacy was reported for formocresol and ferric sulphate. ${ }^{3}$ There are a number of other studies, although not as well conducted, which lead to the same conclusion. In addition I also question whether a fixative is required on radicular pulp that is not usually irreversibly inflamed and is also adequately perfused, adding to its healing potential. ${ }^{4}$ Given this body of evidence for ferric sulphate, I see no reason to dig my heels in and defend formocresol, which in my opinion now has a shadow cast over it and its reputation has been forever tainted. It is the respon- sibility of clinicians who are advocates for children, to make sure what we use is efficacious and free from any links with potential toxicity, and given a perfectly suitable alternative in ferric sulphate, it is perhaps time we should consider giving formocresol up. I therefore concur with views expressed by Dr Mike Casas from Toronto that the use of formocresol is unwarranted in paediatric dentistry. ${ }^{5}$

\section{Duggal, Leeds}

1. Lewis B B. Formocresol in dentistry. Br Dent J 2008; 204: 477

2. Milnes A. Formocresol revisited. Br Dent J 2008; 205: 615.

3. Huth K C, Paschos E, Hajek-Al-Khatar N, Hollweck $\mathrm{R}$ et al. Effectiveness of 4 pulpotomy techniques - randomized controlled trial. J Dent Res 2005; 84: 1144-1148.

4. Duggal M S, Nooh A, High A. Response of the primary pulp to inflammation: a review of the Leeds studies and challenges for the future. Eur J Paediatr Dent 2002: 3: 111-114.

5. Casas M J, Kenny D J, Judd P L, Johnston D H. Do we still need formocresol in pediatric dentistry? J Can Dent Assoc 2005; 71: 749-751.

DOI: 10.1038/sj.bdj.2008.1145

\section{OTC MEDICATIONS}

Sir, we would like to share with your readers the case of a 46-year-old lady who presented in our A\&tE department. She was complaining of a large swelling in the mid-palate which had been present for one week. Prior to the swelling the patient had a short period of tooth pain originating from her upper left lateral incisor. Her medical history was all clear. She smokes 20 cigarettes a day and rinses her mouth twice a day with Listerine.

On examination there was a swelling in the palate approximately $3 \mathrm{~cm}$ in diameter, raised about $1 \mathrm{~cm}$. The swelling was non-tender and fluctuant. There was a central area of necrosis and ulceration (Fig. 1). She is partially dentate and has carious lesions in all remaining teeth. A panoramic radiograph revealed a periapical radiolucency around UL2. Our first impression was that this was a dental abscess arising from UL2; however, when a patient presents with a palatal swelling (especially with ulceration and necrosis) salivary gland malignancy is a suspicion. Drainage was attempted but no pus discharged. An incisional biopsy was taken and antibiotics prescribed.

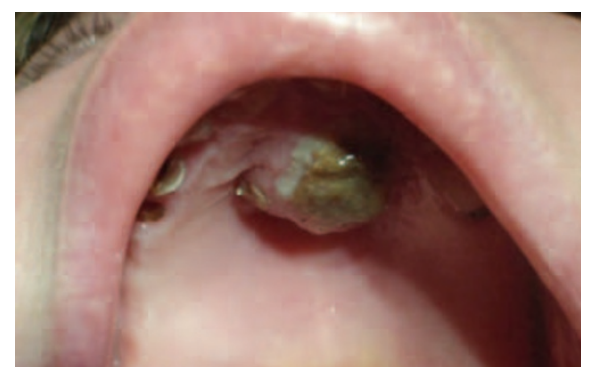

Fig. 1 Large swelling in the mid-palate

Two days later the patient was reviewed and the lesion showed marked improvement, both swelling and ulceration were reduced and the swelling was draining pus. At this point the patient also mentioned that she had used an over-the-counter topical ulcer preparation containing HYBENX ${ }^{\circledR}$ on the initial swelling prior to presentation. HYBENX ${ }^{\circledR}$ is a mixture of sulphuric acid (25-35\% by weight) and sulphonated phenolic acids (30-60\% by weight) and it is likely that this accounts for the ulceration and necrosis by causing a chemical burn to the mucosa. Histological reports were consistent with this hypothesis.

Chemical burns from topically applied salicylic acid preparations are widely reported in the literature and can present as ulcerated or white patches on the mucosa. ${ }^{1,2}$ It is worth noting that aspirin is not the only medicament capable of producing such lesions and that some 
preparations designed for intraoral use can be damaging to the intraoral tissues if used incorrectly. This case highlights the importance of taking a thorough history of a presenting complaint and the need for patients to be aware of the potentially harmful effects of over-thecounter medications.

\section{Lazenby, J. Anderud, M. Millwaters}

Harlow

1. Kawashima Z, Flagg R H, Cox D E. Aspirin-induced oral lesion: report of case. J Am Dent Assoc 1975; 91: 130-131.

2. Sapir S, Bimstein E. Cholinsalicylate gel induced oral lesion: report of case. J Clin Pediatr Dent 2000; 24: 103-106.

DOI: 10.1038/sj.bdj.2008.1146

\section{FORMOCRESOL: A PLEA}

Sir, I write further to my letter published earlier in the year (BDJ 2008; 204: 477) and A. Milne's reply (BDJ 2008; 205: 615).

Having started the debate in $1981^{1}$ I have had the benefit of reviewing the literature $^{2,3}$ as it has developed, without bias and with consistent regard for scientific principles and protocols. Hand-picking studies that have aberrant or inconclusive results when weighed against the accepted evidence becomes self-serving while simultaneously destructive to clinicians seeking the best for their patient. ${ }^{4}$ As recently as March $2008^{5}$ research has shown that formocresol causes genetic damage. Studies using the comet assay have previously produced contrary results when examining peripheral lymphocytes. ${ }^{6}$

Some studies dismiss the addition of cresol without scouring the literature. I am baffled when I read: 'No data currently exist regarding ... environmental sources of cresol' and its inclusion in formocresol is dismissed as unimportant. ${ }^{7}$ Cresol exposure runs the gamut from photographic materials to cigarette smoke and various forms of cresol have been identified as being mutagenic from the early 1980s onward. Newer research shows its genotoxicity to mammalian cells. ${ }^{8}$

I urge dentists to rethink their use of formocresol. Children should not be exposed to formocresol since there isn't any conclusive evidence warranting its use.

\section{B. B. Lewis, Beverly Hills}

1. Lewis B B. Formaldehyde in dentistry: a review of mutagenic and carcinogenic potential. J Am Dent Assoc 1981; 103: 429-434.

2. Myers D R. Distribution of $14 \mathrm{C}$-formaldehyde after pulpotomy with formocresol. J Am Dent Assoc 1978; 96: 805-813.

3. Casas M J, Kenny D J, Judd P L, Johnston D H. Do we still need formocresol in paediatric dentistry. J Can Dent Assoc 2005; 71: 749-751.

4. Milnes A R. Persuasive evidence that formocresol use in pediatric dentistry is safe. $J$ Can Dent Assoc 2006; 72: 247-248.

5. Ramos M E, Cavalcanti B C, Lotufo LV, de Moraes $\mathrm{M} O$ et al. Evaluation of mutagenic effects of formocresol: detection of DNA-protein cross-links and micronucleus in mouse bone marrow. Oral Surg Oral Med Oral Pathol Oral Radiol Endod 2008 105: 398-404.

6. Ribeiro D A, Marques M E, Salvadori D M. Lack of genotoxicity of formocresol, paramonochlorophenol, and calcium hydroxide on mammalian cells by comet assay. J Endod 2004: 30: 593-596.

7. Collaborative Study by Anesthesia and Dentistry Confirms Routine Use of Formocresol in Pediatric Dentistry. Practice Update Winter 2007.

8. Hamaguchi F, Tsutsui T. Assessment of genotoxicity of dental antiseptics: ability of phenol, guaiacol, p-phenolsulfonic acid, sodium hypochlorite, $\mathrm{p}$-chlorophenol, m-cresol or formaldehyde to induce unscheduled DNA synthesis in cultured Syrian hamster embryo cells. Jpn J Pharmacol 2000; 83: 273-276.

DOI: 10.1038/sj.bdj.2008.1147

\section{FULLY CAPABLE}

Sir, does the recent GDC ruling/recommendation on the provision of implant treatment stifle GDP development, reduce dental implant availability to patients, risk an increase in dental tourism for dental implants and artificially increase the cost of dental implants for UK patients? Should such GDC directives be accepted by the profession without consultation if we are truly self-regulating? Surely we should debate such questions.

Should a dentist fail in their duty of care in implant or any treatment a patient can have redress through the courts and should such a claim be substantiated the insurance companies will restrict their practice to limit their financial liability. The GDC might cite a number of complaints as the reason for its action. Is this because implant treatment is now mainstream, being no different from complaints made when other advances in restorative dentistry became commonplace, ie crowns and bridges?

Is it not now appropriate for the GDC to direct the dental schools to teach implant skills to undergraduates? I well remember having to reach a creditable standard prior to being allowed to construct a bridge as an undergraduate which is now routine practice. Dentistry has moved on and implant treatment is now core dentistry and should be taught as an undergraduate.

Currently a dental graduate is expected to be able to reflect a flap, remove bone, elevate tooth roots yet little more training would be needed for the insertion of a simple dental implant. ${ }^{1}$ The construction of crowns and bridges is routinely taught to undergraduates yet it can hardly be claimed that much more skill is required to fix a suprastructure to an osseointegrated implant. I accept that undergraduate implant teaching by the dental schools would increase dental training cost but funding must be found from some source. This would curtail the mushrooming of run for profit, unregulated, expensive implant courses and perhaps the GDC should now dictate a standard. The general public has a right to expect their local GDP to be fully capable of undertaking implant treatment at reasonable cost without the need for specialisation.

G. D. Wood, by email

1. General Dental Council. The first five years: $a$ framework for undergraduate dental education 2nd ed. Paragraph 91. General Dental Council, August 2002.

DOI: 10.1038/sj.bdj.2008.1148

\section{CAUTIONARY TALE}

Sir, I recently had cause to make a claim through my broker to the company with whom I had a practice insurance policy for interruption of electrical supply and loss of earnings for that day. The sum claimed was £945. After lots of to-ing and fro-ing the insurance company only offered me $£ 50$ per chair per practice as compensation, ie $£ 50 \times 2=£ 100$.

It seems ludicrous that you spend $£ 820$ for comprehensive practice insurance and when you need the full claim to be honoured you are offered a derisively insulting sum of $£ 100$.

Why? Because they say you can rebook patients and recoup the earnings! When? In extra time? What is the point of having a policy that doesn't do what it says, ie compensate you for lost earnings and time? Has anybody had a similar experience or have I been mis-sold an office package?

Can anyone recommend a reliable insurance company/package that is designed for a dental surgery to compensate for the loss of earnings and time? I am intending to present this scenario to the ombudsman to see if any mis-selling has taken place.

C. Galise, Chelmsford DOI: 10.1038/sj.bdj.2008.1149 